УДК $165.731=111$

\title{
I. Kant and L. Wittgenstein: Correct Notions for Correct Language-Games
}

\author{
Fanil M. Neganov* \\ Ufa State Aviation Technical University \\ 12 K. Marks Str., Ufa, \\ Republic of Bashkortostan, 450008, Russia
}

Received 12.10.2016, received in revised form 13.12.2016, accepted 18.01.2017

The author attempts to show how modern concepts of space and time, the original principles laid by Immanuel Kant, help take a fresh look at traditional philosophical problems of the material and the ideal, the nature of consciousness, the ratio of sensual and rational in cognition. The author also draws a parallel between the philosophical views of I. Kant and L. Wittgenstein.

Keywords: Notion, material, ideal, thought, consciousness, sensitive, rational, sensation, space, time, I. Kant, L. Wittgenstein.

DOI: 10.17516/1997-1370-0027.

Research area: philosophy.

On one hand, we need to settle the set of notions we use. On the other, carried away with the notion analysis we may get distracted from solving real problems. Obviously, we should not forget that those are the correct notions that enable us to understand the world correctly, and therefore, to find solutions for the real problems.

\section{Notion and its meaning}

A notion hides some meaning assigned to it by an individual. However, one cannot judge what this notion means for the given individual by the notion itself. To do it, one needs to experience the same, in the same quality, which is often impossible.
This individual meaning (physically, in the sense of its influence on spontaneous physical processes, or SPP) may not matter in reality. In other words, it may not change anything in the Universe.

Along with that, individual meaning does matter for social phenomena and for art in particular. But works of art do not exist in spontaneous physical processes; they are created due to the will and intentional activity of man. It means that extinction of the humankind leads to extinction of such artistic forms. They are not supported by SPP, for instance, in the way they support atomic or molecular structures. However, one should note that the emergence of life and the

(C) Siberian Federal University. All rights reserved

* Corresponding author E-mail address: neganov2005@mail.ru 
humankind in the world is also a result of some SPP. One should also note that the emergence of life and the humankind caused weakening of physical dynamics (determinism). Voluntariness (freedom) manifested itself in the macroworld; however, it happened to be just as specific for the microworld (indefiniteness).

The so-called "sense analysis" means an attempt to determine what the author implies by this or that notion. Consider that the sense (=meaning) is assigned arbitrarily, referring to one's own individual feelings, experience, sensations. Concentration on individual experience was the origin of existentialism. Such experience begins gaining social value, but considering that it belongs to an individual, the equal value is obtained by the individual as well.

Behind the notion there stands a theory describing and explaining reality. For example, the notion of "gravity" may imply "gravity force" or "curved space". The first notion was introduced by Isaac Newton earlier than the second one, which was introduced later by Albert Einstein. The second one is considered to be more accurate. Therefore, the notion of "gravity" itself refers to the theory introduced by a scientist, not to his personal experience. Researching the notion of "gravity" is useless; it is necessary to study the theory behind it, and then reality itself which stands behind the theory (the area described by the theory).

In the context of everything said above, let us consider the notion of "space" popular in science and everyday life.

\section{The notion of "space": application in physical and social science}

Notions adopted from physics are not always efficiently applied to humanitarian issues. At least such application does not always lead to the result expected by the author. However, the structure of our language and the rules of our speech do not forbid such experiments. Speaking of the positive effects, they allow expressing the specific details which cannot be conveyed by the existing terminological system of humanitarian science. While the negative effect is the breach of the rule genially formulated by the Medieval nominalist philosopher William of Ockham back in the $14^{\text {th }}$ century: «entities are not to be multiplied beyond necessity». In other words, giving a thing or a phenomenon a new name does not change either the thing or the science. Moreover, it litters the language of science, confuses young researchers unfamiliar with the phenomenon and distracts them from the core of the issue itself. Moreover, as rule, the research of such notions does not contribute anything to the science, creating the illusion of research activity.

However, speaking of "social space", where the physical notion of "space" has already been applied, social scientists are convinced that this category has not been developed yet. While in our opinion, the notion of "space" carries metaphoric meaning in this expression, which excuses the fact of its application; to some extent, it helps expressing the author's idea better and clearer. Let us underline that the notion is used in the metaphoric sense and serves as an auxiliary tool for expressing the scientist's idea.

In natural science, this notion denotes no certain material object. In other words, space means some (abstract) volume which may be filled with air, vacuum, some things etc. While in fact, from the physical point of view, volume does not exist as an independent material substance. A material object (let it be solid, gaseous, liquid, plasma, vacuum etc.) obtains its specific (according to natural law) shape as a matter of nature. This is the shape that may be introduced as volume. Consequently, here volume means an empty shape occupied by a material thing. 
So, now the notion of "space" is clear. It is not an independent material object; it is just a shape the object obtains in the course of its existence. Finding this "empty" shape, without the material thing filling it, becomes possible only due to the amazing ability of human mind. But it may only be done in one's head as a purely ideal abstraction (that was exactly what I. Kant genially remarked classifying "space" as a transcendent category of mind, which we cannot but agree with).

It brings us to a useful conclusion: it is pointless to research space on its own, since it does not exist as an independent material object. We may research vacuum as a material object, air as a material object, things as material objects etc. As all these things have a shape, i.e. they occupy their volume, we may speak of "researching cosmic space" though it implies the research of objects in the volume occupied by cosmos. From this point, the absurdity of such expression "spatial characteristics of social space" becomes especially clear.

But still, what does "social space" mean? According to the above conclusions, it should denote the volume occupied by the social shape of the matter our world consists of. But the issue is complicated by the fact that with the emergence of the social component in the world (as something conceptually different from the biological), we have to speak of the ideal, as the social component is not material. Cost of goods is ideal, but still it is real, which is obvious by its price and convincingly proven by $\mathrm{K}$. Marx. $\mathrm{He}$ fairly remarked that we cannot speak of cost, neglecting the whole material life of man. Without man, without his growing necessities and his labour efforts, without industry and the exchange of its products, without the whole aggregate social being we may not speak of cost in the scientific sense of the word.

Therefore, social shape is specific for it may be both material or non-material, or ideal.
That's what makes it complicated. It is not hard to determine the volume of the material social component, but how can we measure the ideal social one? The ideal is shapeless, it occupies no visible space. It means that the space (=volume) occupied by the social component remains indefinite. It causes the diversity of opinions. It is clear that it is not the volume, or space, which matters for a research, but what the volume is occupied with. Moreover, it is not the space (=volume) that determines the shape of its material object, but it is the material object itself that determines its volume (=space) which it occupies in reality according to its nature.

To conclude, it is the social, i.e. the society and everything that happens within society, which needs to be researched, not the volume the society occupies. The same is true for the socalled "social space".

\section{Does "being in the space" mean "feeling the space"?}

Obviously, being in some space in time should mean feeling such space and time. When I say that I am inside some space, I mean that I am within the atmospheric space of the planet Earth in the Solar system. Or, speaking more globally, that I am in a certain point of the Universe. Together with that, I feel the air around me and I can say whether it is warm or cool, hot or fresh etc. My thermic receptors supply physical impulses to my brain, causing sensations in it. It means, that when I speak of being in some space, I only describe the feelings I get from by thermic receptors. Without them, I would never feel the temperature of the exterior and interior medium. The same can be said of my visual analyser. My eyes can see the things around me, and I am used to evaluating the approximate distance to them; I see and I evaluate the volumes of things and myself, or, in other words, I can see shapes filled with some 
contents and that is what I mean by feeling the space.

Therefore, my judgement of being in some space is directly connected with my sensations produced to my working analysers.

\section{Not the same way... or do we sense thought?}

When it comes to speaking of thoughts, it is commonly believed that we do not sense them and, therefore, they do not exist in space. As a force of habit, people argue that if thoughts were objects, then the increase in their amount in one's life would cause head growth, which does not happen. We should admit that this argument is hardly convincing to modern science. It may have been when it was first said; but it does not mean that it retains the same degree of reason.

This or that way, I may claim that I have some thought, but it is hard to convince others that I sense it because it is impossible to describe its temperature, shape, size, hardness etc. Of course, I may transmit it to someone else (by means of communication) with the help of language and speech, but it would be transmission of the description of the thought, not the thought itself.

Nevertheless, I can put it differently. Let's say I am inspired by sunset, classical music, a natural or a cosmic phenomenon. No one would be surprised, as many people experience similar things. But I may also get inspired by some thought. Does it mean that I experience two different kinds of inspiration? If not, it means that there is no impassable difference between thought and a sense of thing. It also means that I do sense some thought, but not the same way I sense a thing (my reasoning show a tendency of leaving universals with the ultimate statement that everything that happens is strictly individual).

This way, being in space means occupying some place in the Universe and either sense the external or internal medium or not.
Considering the latest achievements of theoretical and experimental physics, we should be critical of the expression of "being in space" itself. Considering the inseparable bond between the material the Universe is made of, space and time, the expression of being in space means occupying some place in the Universe (=being its element) which keeps continuously changing together with you.

Therefore, if one makes a strong bond between the spatial, the temporal and the physical world (=equalling them), being outside space and time would mean being outside the physical world. At the same time, if we want to know what being outside the physical world is, we should admit that a human cannot have such experience. So, it is the same thing as speaking of features of space as such.

Normally we start speaking of space in the presence of an object having a certain shape. Do we see space, and do we feel time when we see no shaped things, when there is nothing but vacuum? Or, to be more precise: to feel vacuum directly, one should either be inside it, or isolate it and feel it when one's own organs of senses. Human organism did not develop in vacuum, so it is an unknown stimulus to human organs of senses. Therefore, vacuum is a physical phenomenon which is impossible to feel with the organs of senses, as it has no shape, or does not consist of atoms and molecules integrated into a certain structure. Therefore, it is wrong to equal physical with space and time.

\section{Source of philosophic dualism}

A dramatic difference of what one feels from what one thinks caused the emergence of two substances in philosophic concepts. A thing is continuous, it exists in space and occupies some place in space. It is inseparable from the physical continuousness of being and, therefore, it exists in time. For this reason, it is not eternal (sooner or 
later, violently or spontaneously, it will be gone), it is divisible. Vice versa, thought is not a thing in the common sense of this word, therefore, it is hard to speak of its spatial location or relation to time. We may only make a hypothesis that is hard to prove.

The world created by man by means of thinking (the world of thought) is opposed to the world of sensual subjects as conceptually different, as, for example, transcendental. Objectivation of this world creates pre-requisites for suggesting their independent existence of thought in the world along with material things. And if such thought entities are regarded as existing beyond space and time, then they exist in eternity (for example, transcendental). Then we have to make a hypothesis of how the eternal and the temporal world are related to each other.

Another problem is the problem of unity of the world, i.e. how to combine the super-temporal and super-spatial characteristics of being with the temporal and spatial ones (if we wish to stick to monism).

\section{Linguistic problem}

Often the obstacle is the linguistic problem, or the problem of meaning (sense) of the used symbols, words, notions, and categories. I. Kant's specification of the notions of "space" and "time" demonstrated that they did not indicate a certain physical object (a physical form of being), but a state of such things (as transcendent notions, tools). Consequently, there may be such states where spatial and temporal characteristics of things (or "things") are either absent or do not manifest themselves in any way.

This way, "being in eternity" means "being in the same world, but under different conditions and circumstances from the temporal and spatial". Therefore, "eternally" may mean "for a very long time". If we speak of the past, it is not clear where we may stop to say: "that is where the eternity ended".

However, let us return to thought. Does it occupy any place in space (or, to be more precise, does it have any spatial characteristics)? One of the possible answers is: "thought occupies some place in the space of mind, but not the same way a table occupies some place in the room; thought exists in time, but not the same way a table does".

To clarify, let us make a mental experiment and imagine a dialogue between two great thinkers.

Wittgenstein (statement):

Meaning of a notion is determined by its use.

Plato (statement):

A real table is divisible, and it can be divided in practice. But the idea of the table (=its ideal form) is indivisible.

\section{Wittgenstein (comment):}

The verb to divide only makes sense for things, but it does not make any sense (=it is a mistake) for ideas (=Plato's ideas). For this reason, we should say: "The idea of the table is indivisible, as it is only a real table that can be divided. We use the same verb, but its meaning changes in different situations of its use".

Therefore, saying that thought is ideal and it does not occupy any place in space, we may mean that thought does not occupy any place in space the same way an atom, a molecule or their combinations do. But we may also say that, considering the fact that the notion of "space" does not mean anything physical, but works as a tool, a transcendental and auxiliary notion, the expression above makes no sense.

But that is when we arrive at mind-body dualism. Though R. Descartes' dualism is just a special case of the idea of multiple independent worlds, unlimitable (=unreducible) to a single one. Or though Wittgenstein's idea of multiple 
language-games is approximately the same. Or so is the idea of Toynbee and Spengler of the multiple independent civilization cultures.

But if we happen to say, "thought does occupy some place in space but not the same way atoms, molecules, cells and tissues of the brain matter do", it may mean that thought and brain matter with its spatial forms share the same nature. It may look as one picture that has another under it, and the second has the third under it etc., all of each sharing the same nature. Transitions from one layer to another are important. Possibly, those are volumes, not layers. It is also possible that these volumes are dynamic, not static. It is also possible that in reality the situation is many times more complicated than the picture example.

\section{Are logic and terminology of the microworld of any use?}

A famous Western science writer Paul Davis in his book titled "Superforce" mentions that physicists had to reject the idea of an electron as of an absolutely hard ball, and the electron became regarded as a point having no structure or dimensions (Davis, P. Superforce. Moscow, 1989. P. 119).

Similarly, we may say (and it should not confuse us) that consciousness is also something having no structure or dimensions. Physicists and chemists have different idea of what an electron is. They describe its features and characteristics. They know its charge. They know lots of things we do not mention here. But all these describe something which has no structure or dimensions. However, no one doubts the existence of the electron, i.e. the existence of something having no structure or dimensions. In the same way, when we speak of consciousness, we may also just speak of something having no structure or dimensions. In other words, why cannot we apply terms and logic of the microworld, not only to the macroworld, but to the description of consciousness? At least, it would mean that pointing out two independent substances, the continuous and the non-continuous, the physical and the thinking ones (R. Descartes) makes no sense anymore.

\section{Time}

Speaking of space, we should also mention the notion of time, applying the style and logic of thinking the reader should have noticed above. The most popular hypothesis of modern cosmology claims that the first event in our Universe was the so-called Big Bang. That it was when the Universe was born. It gave start to space (=the material the Universe is made of acquired the form and qualities we describe with the notion of "space") and processes, which means that it was beginning of time, the Universe time... and relative time. However, this time should be understood as a process, continuity of spontaneous events happening in the Universe after the Big Bang. That is how the four well-known dimensions of the world we live in appeared.

Our Universe, born from the Big Bang, is a single whole consisting of interconnected parts, possessing its own time. However, it would be wrong to extrapolate time on all internal events of our Universe as something common. Time flows differently at the foundation and on the roof of a skyscraper due to the difference of gravity force. However, considering that the difference of time is minor, we may neglect it and average the time. Similarly, we may average all time of our Universe to speak of a common internal time which would be different from that of another Universe, external in relation to ours.

This understanding of time considering the latest achievements of modern physics and mathematics seems to be the most accurate. It means, that when someone uses the notion of "time" and if the author claims to state it's the only true, genuine physical (or universal) meaning different from the one above, they should either upturn the existing interpretation of time or come 
up with a new one, more convincing from the point of view of modern natural science. It means, that when the notion of "time" is used, it assumes the procedurality of the happening physical event, and that nothing concerning the meaning of this event can be extracted from the notion.

It seems that the so-called "notion analysis" cannot replace the analysis of what it really means. But it is a common mistake of some modern researchers.

This replacement was actively criticized by K. Popper. For example, in his book titled "The Self and Its Brain", written in cooperation with John Eckles who won the Noble Prize in Biology, he wrote:

"In general I try to avoid "what is" questions, and even more "what do you mean by" questions, because they seem to me prone to produce the danger of substituting verbal problems (or problems about meaning) for real ones" (The Self and Its Brain: An Argument for Interactionism (with J.C. Eccles). Routledge, London and New York, 1998, p. 9).

Here we see a bright manifestation of Kant's idea that the human mind builds its idea of the world through transcendental notions, i.e. notions, categories, and symbols he assigns arbitrary meanings to. The man cannot know what the world is as it is due to his limited cognition capacity. "Space" and "time" are also classified as such transcendental notions. It is pointless to speak of space as such and time as such, we should not waste our time on it; we should speak of what they mean in reality.

It also means that the total of notions and rules for their use adopted by mean is a language-game (L. Wittgenstein) which may lead us to a dead end or help finding a more accurate idea of the world. We should also say that there are lots of language-games, and they may have no bridges connecting them. The randomness of such intercrossings leading to the misconception of terms causes the breach of rules and distortion of the world outlook.

\title{
И.Кант и Л.Витгенштейн: правильные понятия
}

\section{Для правильных языковых игр}

\author{
Ф.М. Неганов \\ Уфимский государственный авиационный \\ технический университет \\ Россия, 450008, Республика Башкортостан, \\ Уфа, ул. К. Маркса, 12
}

В данной статье автором делается попытка показать, как современное содержание понятий пространства и времени, исходные принципы, определения которых были заложены еще И.Кантом, помогают по-новому взглянуть на традиционные философские проблемы материального и идеального, природы сознания, соотношения чувственного и рационального в познании. Автор статьи также проводит параллель между философскими воззрениями И.Канта и Л.Витгенштейна.

Ключевые слова: понятие, смысл, материальное, идеальное, мысль, сознание, чувственное, раицональное, ощущение, пространство, время, И.Кант, Л.Витгенштейн.

Научная специальность: 09.00.00 - философские науки. 